\title{
Penicillin resistance in the intestinal spirochaete Brachyspira pilosicoli associated with OXA-136 and OXA-137, two new variants of the class $D$ $\beta$-lactamase OXA-63
}

\author{
Sheila M. Mortimer-Jones, Nyree D. Phillips, Tom La, Ram Naresh \\ and David J. Hampson
}

Correspondence

David J. Hampson

d.hampson@murdoch.edu.au

Received 27 February 2008

Accepted 28 April 2008

\author{
School of Veterinary and Biomedical Sciences, Murdoch University, Murdoch, Western Australia \\ 6150, Australia
}

\begin{abstract}
Penicillin resistance mediated by $\beta$-lactamase activity has been reported previously in the anaerobic intestinal spirochaete Brachyspira pilosicoli, and a novel class D $\beta$-lactamase (OXA63) hydrolysing oxacillin was described recently in a resistant human strain from France. In the current study, 18 B. pilosicoli strains from Australia and Papua New Guinea were tested for ampicillin and oxacillin susceptibility, and investigated for the presence of the class $D \beta$-lactamase gene bla OXA-63 $_{3}$ using PCR. PCR products were amplified from seven human and four porcine strains that were penicillin resistant, but not from seven penicillin-sensitive strains. Sequence analysis of the whole gene amplified from seven of the resistant strains from humans and pigs revealed only minor nucleotide differences among them, but there were significant differences compared with blaOXA-63. The predicted amino acid sequence of the enzyme from all seven strains had the same key structural motifs as the previously reported OXA-63, but two variants with 94$95 \%$ identity with OXA-63 were identified. OXA-136 had an additional amino acid and 12 other consistent amino acid substitutions compared with OXA-63. OXA-137 had the same differences compared with OXA-63 as OXA-136, but had an additional amino acid substitution at position 16. No structures consistent with integrons or transposons were found in the nucleotide sequences in the vicinity of bla OXA-136 in partially sequenced B. pilosicoli strain 95/1000, and the GC content (25.2 mol\%) of the gene was similar to that of the whole genome. The gene encoding OXA-136 from B. pilosicoli strain Cof-10 conferred penicillin resistance on Escherichia coli. This study shows that penicillin resistance in human and porcine B. pilosicoli strains from Australia is associated with the production of two variants of OXA-63, and that susceptible strains lack the genes encoding OXA-63 or the variants.
\end{abstract}

\section{INTRODUCTION}

The anaerobic intestinal spirochaete Brachyspira pilosicoli (formerly Serpulina pilosicoli) colonizes the large intestine of a range of species, including humans, pigs, chickens, ducks, dogs and horses (Hampson et al., 2006a). The spirochaete is transmitted via the faecal-oral route, but probably also indirectly in drinking water contaminated by human or animal faeces (Oxberry et al., 1998; Margawani et al., 2004; Munshi et al., 2004). B. pilosicoli is considered to be potentially zoonotic (Hampson et al., 2006a). Once established in the large intestine, the spirochaete may attach by one cell end to the colorectal epithelium to form

Abbreviation: PNG, Papua New Guinea.

The GenBank/EMBL/DDBJ accession numbers for the $\beta$-lactamase genes from strains WesB, 95/1000, Cof-10, Gap 51.2, H/A1, H/A2 and $\mathrm{H} / \mathrm{A} 3$ are EU086830-EU086836, respectively. a 'false brush border', in a condition called intestinal spirochaetosis (Harland \& Lee, 1967; Mikosza \& Hampson, 2001; Hampson \& Duhamel, 2006). A similar histological picture occurs following colonization with the related spirochaete Brachyspira aalborgi (Mikosza \& Hampson, 2001). In humans, colonization with these spirochaetes can be associated with a variety of non-specific problems, including chronic diarrhoea, abdominal discomfort and failure to thrive in children (Douglas \& Crucioli, 1981; Brooke et al., 2006; Esteve et al., 2006). Infection with $B$. pilosicoli occurs commonly in intensively farmed pigs and chickens, in which it is considered to be an important enteric pathogen, and also in people living in crowded and unhygienic conditions in developing countries (Trott et al., 1997a; Margawani et al., 2004; Munshi et al., 2004). Although colonization of humans is rare among the general population in developed countries, in Australia up to $30 \%$ 
of faecal specimens from rural Aboriginal Australians may contain B. pilosicoli (Lee \& Hampson, 1992; Brooke et al., $2001,2006)$ and the spirochaete has been isolated from the faeces or from rectal biopsies of $30-50 \%$ of homosexual males and individuals with human immunodeficiency virus (Law et al., 1994; Trivett-Moore et al., 1998). Spirochaetaemias with $B$. pilosicoli have been reported in individuals who are debilitated for reasons such as chronic alcoholism or neoplastic conditions (Fournié-Amazouz et al., 1995; Trott et al., 1997b; Kanavaki et al., 2002).

Penicillin has been used to treat intestinal spirochaetosis (Kanavaki et al., 2002; Lima et al., 2005), but resistance to penicillin has been reported among $B$. pilosicoli isolates from humans, pigs and chickens (Tompkins et al., 1987; Brooke et al., 2003; Dassanayake et al., 2005; Hampson et al., 2006b). Furthermore, by using nitrocefin, $\beta$-lactamase activity has been identified in penicillin-resistant strains of B. pilosicoli (Tompkins et al., 1987; Brooke et al., 2003). Clavulanic acid enhances the activity of penicillin, ampicillin and amoxicillin against resistant B. pilosicoli (Tompkins et al., 1987; Brooke et al., 2006), and this initially suggested the presence of a class A $\beta$-lactamase (Ambler, 1980; Bush et al., $1995)$. However, analysis of near-complete ( $~ 90 \%)$ genomic sequence data from the ampicillin-resistant porcine strain $95 / 1000$ has failed to identify class A $\beta$-lactamase genes (T. La \& D. J. Hampson, unpublished data). Furthermore, class A genes have not been found in any spirochaete species to date. Recently, a novel membrane-bound group VI class D $\beta$ lactamase that hydrolyses oxacillin, called OXA- 63 , has been described in B. pilosicoli strain BM4442 isolated from a human in France (Meziane-Cherif et al., 2008; GenBank accession nos AY619003 and AAU88145 for the nucleotide and amino acid sequences, respectively).

The purpose of the current study was to look for $b l a_{\mathrm{OXA}-63}$, the gene encoding OXA-63, in a collection of B. pilosicoli strains from humans in Australia and Papua New Guinea (PNG), and in strains from pigs, and to determine to what extent it is associated with penicillin resistance in B. pilosicoli.

\section{METHODS}

Spirochaete strains. Eighteen strains of B. pilosicoli from the culture collection held at the Reference Centre for Intestinal Spirochaetes at Murdoch University, Australia, were used. These included six strains isolated from the faeces of Australian Aborigines, one strain from an Australian homosexual male, seven strains from villagers in the highlands of PNG and four strains from Australian pigs. Five of the human strains from Aborigines, the strain from the homosexual male and two of the porcine strains have been shown in a previous study to be resistant to amoxicillin, to have this susceptibility restored by clavulanic acid and to have $\beta$-lactamase activity as assessed using nitrocefin discs (Brooke et al., 2003).

Medium, culture conditions and antimicrobial susceptibility testing. $B$. pilosicoli strains were subcultured on trypticase soy agar (TSA; BBL Microbiology Systems) plates containing $5 \%$ defibrinated ovine blood. The cells were grown for 1 week at $37{ }^{\circ} \mathrm{C}$ in an anaerobic jar, with an atmosphere of $94 \% \mathrm{H}_{2}$ and $6 \% \mathrm{CO}_{2}$ generated using a GasPak Plus gas generator envelope (BBL). A zone of haemolysis around the inoculated culture indicated growth, which was confirmed by resuspending surface growth in PBS and examining for motile spirochaetes using a phase-contrast microscope at a magnification of $\times 400$.

All of the strains were tested for susceptibility to ampicillin, and eight resistant strains (five from Aboriginal Australians, one from a homosexual male and two porcine strains) were also tested with ampicillin plus clavulanic acid, oxacillin, and oxacillin plus clavulanic acid. Doubling dilutions of ampicillin were used with concentrations of $1-128 \mu \mathrm{g} \mathrm{ml}^{-1}$; clavulanic acid was tested in combination with ampicillin at a ratio of $4: 1$. Oxacillin was tested at 0.06 and $0.125 \mu \mathrm{g}$ $\mathrm{ml}^{-1}$ and then at doubling dilutions up to $128 \mu \mathrm{g} \mathrm{ml}^{-1}$; clavulanic acid was added to oxacillin at a ratio of $4: 1$. Antimicrobial susceptibility was assessed using the agar-dilution method, with all tests conducted in quadruplicate. The test plates consisted of TSA containing $5 \%$ defibrinated ovine blood and the appropriate antibiotic concentration. Control plates did not include antibiotics.

Inocula were prepared by adding $1 \mathrm{ml}$ sterile PBS to plates containing pure cultures and resuspending the cells. These were counted using a haemocytometer chamber viewed under a phase-contrast microscope, diluted in PBS and $10^{5}$ cells of each strain were stab-inoculated onto the test and control plates (CLSI, 2007). The plates were incubated for 5 days at $37{ }^{\circ} \mathrm{C}$ in anaerobic jars, with an atmosphere of $94 \% \mathrm{H}_{2}$ and $6 \% \mathrm{CO}_{2}$, and then observed for haemolysis. The first sensitive colony zone and the last resistant colonies were checked for spirochaete growth using a phase-contrast microscope at a magnification of $\times 400$. The MIC was reported as the lowest concentration of antimicrobial that inhibited growth.

Presence of blaoxa-63 in B. pilosicoli 95/1000. The partial ( $\sim 90 \%$ ) genome sequence of porcine B. pilosicoli strain 95/1000 was examined for the presence of $b l a_{\mathrm{OXA}-63}$ using BLAST homology analysis with international nucleotide and protein databases as well as conserved domain searches using the NCBI Conserved Domains Database (www.ncbi.nlm.nih.gov/Structure/cdd/cdd.shtml). The genome sequence in the regions flanking the gene also was examined for motifs consistent with transposable elements, such as transposons and integrons, which may show evidence of horizontal gene transfer.

DNA isolation and manipulations. Basic recombinant DNA procedures were carried out according to standard protocols (Sambrook et al., 1989). Chromosomal DNA was prepared from bacterial cells using a DNeasy Tissue kit (Qiagen) and plasmid DNA was purified using a QIAprep Spin Miniprep kit (Qiagen).

PCR. For PCR assays, the amplification mixture consisted of $1 \times$ PCR buffer (containing $1.5 \mathrm{mM} \mathrm{MgCl}$ ), $0.5 \mathrm{U}$ Taq DNA polymerase (Fisher Biotech), $0.2 \mathrm{mM}$ each dNTP (Promega), $0.5 \mu \mathrm{M}$ of the primer set and 50-100 ng chromosomal template DNA in a total volume of $50 \mu \mathrm{l}$. Cycling conditions involved an initial denaturation at $94{ }^{\circ} \mathrm{C}$ for $5 \mathrm{~min}$, followed by 30 cycles of denaturation at $94{ }^{\circ} \mathrm{C}$ for $30 \mathrm{~s}$, annealing at $55{ }^{\circ} \mathrm{C}$ for $30 \mathrm{~s}$ and primer extension at $72{ }^{\circ} \mathrm{C}$ for $2 \mathrm{~min}$. The PCR products were separated by electrophoresis in $1.5 \%$ $(w / v)$ agarose in Tris/acetate buffer $(40 \mathrm{mM}$ Tris/acetate, $1 \mathrm{mM}$ EDTA), stained with a $1 \mu \mathrm{g}$ ethidium bromide $\mathrm{ml}^{-1}$ solution and viewed using UV light.

PCR amplifications, and sequencing of bla oxA-63. Three pairs of oligonucleotide primers that annealed to two regions internal to and one external to the $807 \mathrm{bp} b l a_{\mathrm{OXA}-63}$ coding sequence in the whole genomic sequence of $B$. pilosicoli strain 95/1000 were designed using the Primer3 program (Rozen \& Skaletsky, 2000) and synthesized by Geneworks. The three PCRs were optimized for the detection of bla $a_{\mathrm{OXA}-63}$ using chromosomal DNA from all 18 strains of B. pilosicoli. The external primer set consisted of Bp-oxa-US (5'-TTTGGTTTTCAAGGCTCAACAG-3') and Bp-oxa-DS (5'-GCTTTAGATATTGCT- 
TTTTTGGC-3'), which annealed to complementary sequences adjacent to the coding region of $b l a_{\mathrm{OXA}-63}$. The two internal primer sets consisted of Bp-lac1-F192 (5'-AAGATTTTATCCAGCATCAAC$\left.3^{\prime}\right)$ and Bp-lac1-R634 (5'-ATCCAGTTTTTCCATGAAGC-3'), which amplified a $450 \mathrm{bp}$ region within the coding region of $b l a_{\mathrm{OXA}-63}$, and Bp-oxa-F484 (5'-CCTTTGGAAATAAGTGCGATGGAGCAAG-3') and Bp-oxa-R692 (5'-TCAAGCCAGCCTACGAACCAACC-3'), which amplified a 209 bp region within the coding region.

PCR products generated by the external primer set were purified using an UltraClean PCR Clean-up kit (Mo Bio Laboratories). The products from seven ampicillin-resistant strains of B. pilosicoli were sequenced in both directions using the ABI PRISM Dye Terminator Cycle Sequencing Ready Reaction Mix (PE Applied Biosystems), using the same primers. The sequence results were edited and compiled using VectorNTI Advance 10 (Invitrogen). The sequences were aligned using CLUSTAL_X (Sun et al., 2003) and compared for similarity among themselves and with known class $\mathrm{D} \beta$-lactamase genes in GenBank.

Cloning of the B. pilosicoli $\beta$-lactamase gene into Escherichia coli JM109. The entire 807 bp coding region of the $\beta$-lactamase gene was amplified from $B$. pilosicoli strain Cof-10 using the primers Bp-oxa-F-EcoRI (5'-CAAGGAATTCCAGATGGAAGATACTATATTGCTATG-3') and Bp-oxa-R-XhoI (5'-TTTTCTCGAGTTTAGATATTGCTTTTTTGGC-3') and cloned into plasmid pBK-CMV (Stratagene), which was digested with EcoRI and XhoI. The recombinant plasmid (designated $\mathrm{pBK}-b l a_{\mathrm{BP}-1}$ ) was transformed into E. coli JM109 (Promega) and plated onto Luria-Bertani agar supplemented with $50 \mu \mathrm{g}$ kanamycin $\mathrm{ml}^{-1}$. Plates were incubated at $37{ }^{\circ} \mathrm{C}$ overnight. The plasmids from two ampicillin-resistant clones were purified using a QIAprep Spin Miniprep kit (Qiagen) and sequenced as described above using the T3 (5'-AATTAACCCTCACTAAAGGG-3') and T7 (5'-CGGGATATCACTCAGCATAATG-3') vector primers.

\section{RESULTS}

\section{Antimicrobial susceptibility}

The results of the in vitro antimicrobial susceptibility tests are presented in Table 1. All strains grew on the control plates containing TSA and 5\% defibrinated ovine blood. The CLSI (2007) guidelines do not give MIC breakpoints for ampicillin for B. pilosicoli, but an MIC $>2 \mu \mathrm{g} \mathrm{ml}^{-1}$ is considered to indicate resistance in Gram-negative anaerobes. Using this definition, all seven strains from PNG villagers were sensitive to ampicillin, whereas all six Aboriginal strains, the strain obtained from a homosexual male and the four porcine strains were clearly resistant. The ampicillin-resistant strains that were tested had reduced MICs following the addition of clavulanic acid. The strains tested for ampicillin/clavulanic acid sensitivity were also tested with oxacillin. Again, there are no guidelines for MIC breakpoints for Brachyspira species against oxacillin; however, all eight ampicillin-resistant strains tested had MICs of $>128 \mu \mathrm{g} \mathrm{ml}^{-1}$ for oxacillin, which indicates significant resistance. In five out of eight cases, the addition of clavulanic acid to oxacillin reduced the MIC.

Table 1. B. pilosicoli strains investigated and the results of antimicrobial susceptibility tests

CA, Clavulanic acid; NT, not tested.

\begin{tabular}{|c|c|c|c|c|c|}
\hline \multirow[t]{2}{*}{ Strain } & \multirow[t]{2}{*}{ Origin } & \multicolumn{4}{|c|}{$\mathrm{MIC}\left(\mu \mathrm{g} \mathrm{ml}^{-1}\right)$} \\
\hline & & Ampicillin & Ampicillin/CA & Oxacillin & Oxacillin/CA \\
\hline $\mathrm{H} 21^{\star}$ & Aboriginal & $>128$ & NT & NT & NT \\
\hline $\mathrm{H} / \mathrm{A} 1^{*} \dagger$ & Aboriginal & $>128$ & 32 & $>128$ & 64 \\
\hline $\mathrm{H} / \mathrm{A} 2^{\star} \dagger$ & Aboriginal & $>128$ & 32 & $>128$ & 64 \\
\hline $\mathrm{H} / \mathrm{A} 3^{*} \dagger$ & Aboriginal & $>128$ & 32 & $>128$ & $>128$ \\
\hline $\mathrm{H} / \mathrm{A} 4^{*}$ & Aboriginal & $>128$ & 32 & $>128$ & 64 \\
\hline Wes- $B^{*} \dagger$ & Aboriginal & $>128$ & 32 & $>128$ & $>128$ \\
\hline Gap $51.2^{\star} \dagger$ & Homosexual male & $>128$ & 32 & $>128$ & 64 \\
\hline Cof $-10^{\star} \dagger$ & Pig & $>128$ & 16 & $>128$ & $>128$ \\
\hline $95 / 1000^{*} \dagger$ & Pig & $>128$ & 16 & $>128$ & 64 \\
\hline OF15* & Pig & $>128$ & NT & NT & NT \\
\hline Q1588.5* & Pig & $>128$ & NT & NT & NT \\
\hline V4 H29 & PNG villager & $<1$ & NT & NT & NT \\
\hline V1 H7 & PNG villager & $<1$ & NT & NT & NT \\
\hline V1 H11 & PNG villager & $<1$ & NT & NT & NT \\
\hline V4 H8 & PNG villager & $<1$ & NT & NT & NT \\
\hline V2 H88 & PNG villager & $<1$ & NT & NT & NT \\
\hline V1 H56 & PNG villager & 2 & NT & NT & NT \\
\hline V1 H141 & PNG villager & $<1$ & NT & NT & NT \\
\hline
\end{tabular}

${ }^{\star}$ Strains previously shown to be resistant to amoxicillin and to have $\beta$-lactamase activity using nitrocefin discs. In contrast, the strains from PNG were susceptible to amoxicillin and lacked $\beta$-lactamase activity (Brooke et al., 2003).

$\dagger$ Strains from which $b l a_{\text {OXA-63 }}$ was sequenced. 
Table 2. Sites of nucleotide differences in bla ${ }_{\mathrm{OXA}-63}$ from French B. pilosicoli strain BM4442 and seven Australian strains

\begin{tabular}{|c|c|c|c|c|c|c|c|c|}
\hline \multirow{2}{*}{ Base position ${ }^{\star}$} & \multicolumn{8}{|c|}{ B. pilosicoli strain } \\
\hline & BM4442 & Gap51.2 & $95 / 1000$ & Cof-10 & WesB & H/A1 & H/A2 & H/A3 \\
\hline 47 & $\mathrm{~T}$ & $\mathrm{~T}$ & $\mathrm{~T}$ & $\mathrm{~T}$ & $\mathrm{~T}$ & $\mathrm{C}$ & $\mathrm{C}$ & $\mathrm{C}$ \\
\hline 287 & - & A & A & A & A & A & A & A \\
\hline 300 & G & A & A & A & A & A & A & A \\
\hline 301 & - & G & G & G & G & G & G & G \\
\hline 302 & - & $\mathrm{T}$ & $\mathrm{T}$ & $\mathrm{T}$ & $\mathrm{T}$ & $\mathrm{T}$ & $\mathrm{T}$ & $\mathrm{T}$ \\
\hline 306 (309) & $\mathrm{C}$ & $\mathrm{C}$ & $\mathrm{T}$ & $\mathrm{T}$ & $\mathrm{T}$ & $\mathrm{T}$ & $\mathrm{T}$ & $\mathrm{T}$ \\
\hline $321(324)$ & A & $\mathrm{A}$ & G & G & G & G & G & G \\
\hline $394(397)$ & A & $\mathrm{C}$ & $\mathrm{C}$ & $\mathrm{C}$ & $\mathrm{C}$ & $\mathrm{C}$ & $\mathrm{C}$ & $\mathrm{C}$ \\
\hline $508(511)$ & G & G & G & G & G & A & A & A \\
\hline $545(548)$ & A & $\mathrm{C}$ & $\mathrm{C}$ & $\mathrm{C}$ & $\mathrm{C}$ & $\mathrm{C}$ & $\mathrm{C}$ & $\mathrm{C}$ \\
\hline $571(574)$ & A & A & G & G & G & G & G & G \\
\hline 588 (between 591 and 592) & $\mathrm{T}$ & - & - & - & - & - & - & - \\
\hline $606(608)$ & - & A & A & A & A & A & A & A \\
\hline $607(610)$ & A & $\mathrm{T}$ & $\mathrm{T}$ & $\mathrm{T}$ & $\mathrm{T}$ & $\mathrm{T}$ & $\mathrm{T}$ & $\mathrm{T}$ \\
\hline $688(611)$ & $\mathrm{T}$ & A & A & A & A & A & A & A \\
\hline $708(711)$ & $\mathrm{C}$ & $\mathrm{C}$ & $\mathrm{T}$ & $\mathrm{T}$ & $\mathrm{T}$ & $\mathrm{T}$ & $\mathrm{T}$ & $\mathrm{T}$ \\
\hline $735(738)$ & $\mathrm{C}$ & $\mathrm{C}$ & $\mathrm{C}$ & $\mathrm{C}$ & $\mathrm{C}$ & A & A & A \\
\hline
\end{tabular}

${ }^{\star}$ Base position in $b l a_{\mathrm{OXA}-63}$ from the French B. pilosicoli strain BM4442, with the base position in the seven Australian strains shown in parentheses.

\section{PCR detection of bla OXA-63}

PCR products of the correct predicted size were generated using the two PCRs with primers internal to $b l a_{\mathrm{OXA}-63}$ and a PCR using primers external to the gene from all 11 strains that were resistant to ampicillin. No products were generated from the seven ampicillin-sensitive strains.

\section{Sequence of bla}

The 807 bp nucleotide sequences of the $\beta$-lactamase genes in the seven penicillin-resistant strains were very similar to each other, differing by only $1-3 \mathrm{bp}$. The $b l a_{\mathrm{OXA}-63}$ gene from French human strain BM4442 was previously reported to have a coding sequence of 807 bp (MezianeCherif et al., 2008), but this should have been recorded as $804 \mathrm{bp}$, as the sequence included a stop codon. The seven sequences obtained in the current study had between 8 and 17 bp differences compared with the $b l a_{\text {OXA-63 }}$ sequence in strain BM4442, including four consistent insertions and one deletion that resulted in frame-shifts (Table 2).

\section{Structure of OXA-63 and the new variants}

Consistent with a previous report (Meziane-Cherif et al., 2008), the $804 \mathrm{bp} b$ blaXA-63 $_{\text {Oene of French } B \text {. pilosicoli }}$ strain BM4442 was predicted to encode a 268 -amino-acid protein with the structural features of a class $\mathrm{D} \beta$ lactamase. The enzymes in the seven sequenced strains in the current study were predicted to represent two new variants of OXA-63. They all had 12 amino acid differences from OXA-63 in strain BM4442, and had one additional amino acid, such that they both comprised 269 amino acids (Fig. 1). The common differences from OXA-63 occurred in three regions (OXA-63 numbering): (i) in amino acids 96-98, where they had Ile-Asn-Gly rather than Leu-Met-Ala, followed by an insertion of a new amino acid (Glu), and a substitution of Val for Ser at amino acid 100; (ii) in amino acid 182, where they had Pro instead of Gln; (iii) in amino acids 196-202, where they had Leu-Glu-Gln-Thr-Tyr-Asn-Tyr rather than ThrArg-Ala-Asn-Leu-His-Ile. These differences did not affect the key structural sites on the enzyme. In addition to this form of variant, designated OXA-136, which was found in strains Gap51.5, 95/1000, Cof-10 and WesB, strains H/A1, H/A2 and H/A3 also differed at amino acid position 16 (OXA-63 numbering), where they had Thr rather than an Ile (Fig. 1). This second variant was designated OXA-137. The predicted molecular mass and $\mathrm{pI}$ values of OXA-63 and the two variants are presented in Table 3.

\section{Cloning of bla $\mathrm{OXA}_{-136}$ into $E$. coli}

Cloning of $b l a_{\mathrm{OXA}-136}$ from B. pilosicoli strain Cof-10 conferred ampicillin resistance on E. coli JM109.

\section{Analysis of the contig containing bla OXA-136 in the $B$. pilosicoli 95/1000 genomic sequence}

The $b l a_{\mathrm{OXA}-136}$ gene was identified as a single copy in the $B$. pilosicoli strain 95/1000 genome sequence, confirming its 

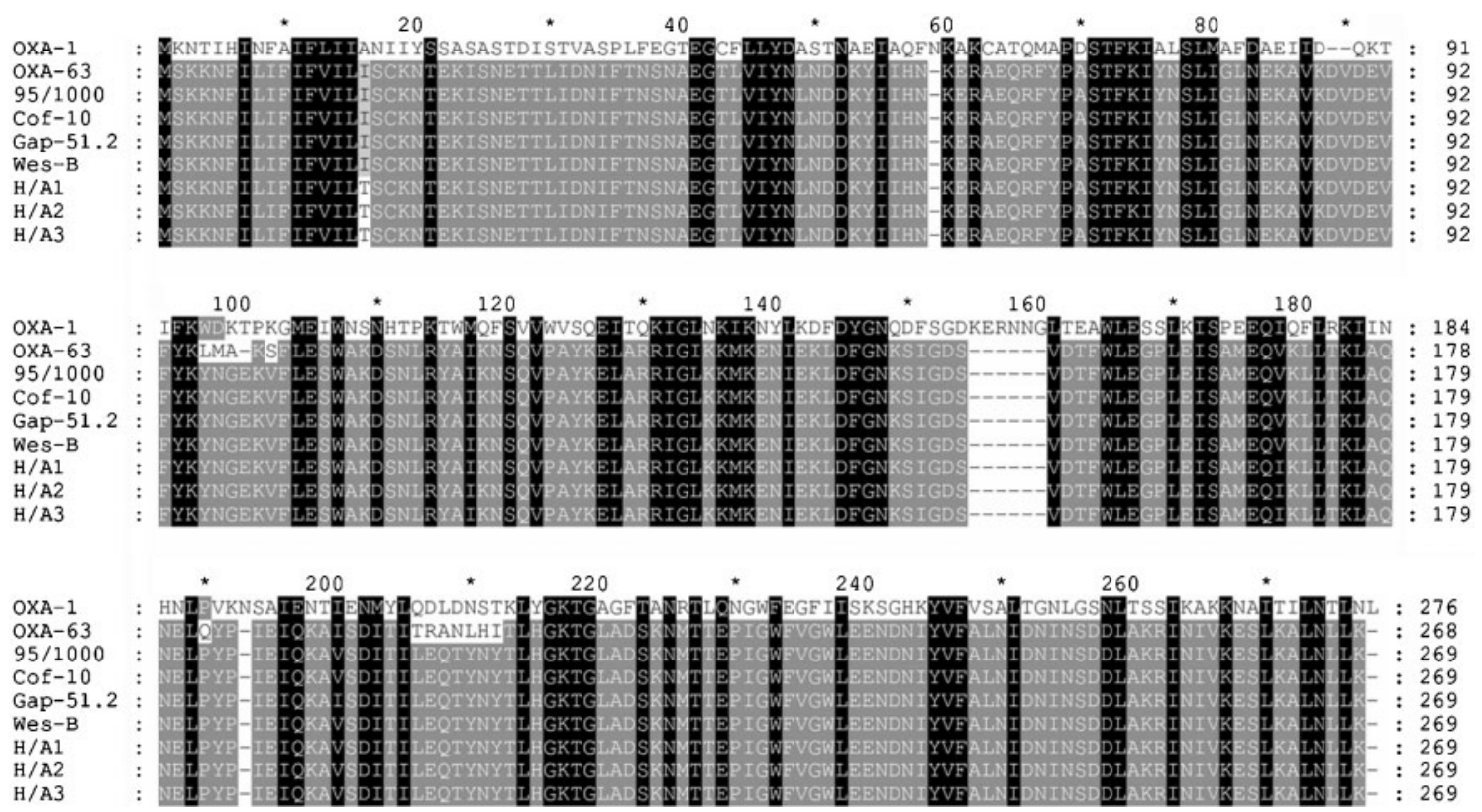

Fig. 1. Amino acid sequence alignment of OXA-1 from E. coli (Sun et al., 2003) and class $D$ enzymes of French human $B$. pilosicoli strain BM4442 (OXA-63) (Meziane-Cherif et al., 2008), porcine B. pilosicoli strains 95/1000 and Cof-10, and the five human B. pilosicoli strains Gap 51.2, Wes-B, H/A1, H/A2 and H/A3. All position numbers are based on the OXA-1 enzyme (Sun et al., 2003).

chromosomal location. The contig containing $b l a_{\text {OXA-136 }}$ had no integrase or tRNA genes in the regions from $\sim 4500 \mathrm{bp}$ upstream to $\sim 10000 \mathrm{bp}$ downstream from the gene. The GC content of the 95/1000 bla OXA-136 $_{\text {gene was }} 25.2 \mathrm{~mol} \%$, whilst the mean GC content for the whole contig was $27 \mathrm{~mol} \%$ (both values were similar to that of the whole genome content: $24.6 \mathrm{~mol} \%$ ). Putative -10 (TATACT) and -35 (TTGACA) promoter sites were located at positions -31 and -53 from $b l a_{\mathrm{OXA}-136}$, whilst a ribosome-binding site (AAGGA) was present $6 \mathrm{bp}$ upstream from an ATG initiation codon, leading to an 807 bp coding sequence.

\section{DISCUSSION}

This study builds on previous work, confirming that some strains of $B$. pilosicoli are susceptible to penicillin, whilst

Table 3. Predicted molecular mass, pl and percentage identity of OXA-85 from F. nucleatum subsp. polymorphum and OXA63, OXA-136 and OXA-137 from B. pilosicoli

\begin{tabular}{|lccc|}
\hline Enzyme & $\begin{array}{c}\text { Predicted molecular } \\
\text { mass (kDa) }\end{array}$ & $\begin{array}{c}\text { Predicted } \\
\text { pI }\end{array}$ & $\begin{array}{c}\text { \% identity with } \\
\text { OXA-85 }\end{array}$ \\
\hline OXA-85 & 29.7 & 6.11 & 100 \\
OXA-63 & 30.7 & 7.58 & 54 \\
OXA-136 & 30.9 & 5.51 & 56 \\
OXA-137 & 30.9 & 5.51 & 56 \\
\hline
\end{tabular}

others are not (Brooke et al., 2003). The fact that penicillin susceptibility was restored with clavulanic acid indicates the presence of a $\beta$-lactamase. No class A $\beta$-lactamase genes were identified in the genomic sequence of strain 95/1000, but the primers designed to amplify the newly described class D $\beta$-lactamase OXA-63 produced specific products, which were found in all of the ampicillin- and oxacillinresistant strains. In contrast, using three separate PCRs targeting sequences internal and external to $b l a_{\text {OXA-63 }}$, there was no evidence of this gene being present in the seven penicillin-susceptible strains (all from PNG villagers). This initial finding was consistent with penicillin resistance in the $B$. pilosicoli strains being due to the presence of the class D $\beta$-lactamase OXA-63.

A description of OXA-63 and the gene encoding it from the French human strain BM4442 has been given previously (Meziane-Cherif et al., 2008). The gene and the $\beta$-lactamase were contrasted with those of their nearest ancestral relations, $b l a_{\mathrm{FUS}-1}$ and FUS-1 (OXA-85), respectively, from Fusobacterium nucleatum subsp. polymorphum, as well as with other OXA-type enzymes (Voha et al., 2006). OXA-63 shares $54 \%$ sequence identity with OXA-85 (Table 3).

The translated amino acid sequences from the seven $B$. pilosicoli strains investigated all showed consistent differences from that of the original OXA-63 in strain BM4442. Nucleotide substitutions, deletions and insertions were such that the translated enzymes shared only 94 or $95 \%$ identity with OXA-63. OXA-136 had 12 amino acid substitutions and one additional amino acid compared 
with OXA-63, whilst OXA-137 had these same differences as well as another amino acid substitution at position 16 . All seven strains containing the variants came from Australia, with OXA-136 being found in strains from one homosexual male, one Aboriginal individual and two pigs, whilst OXA-137 was found in three strains from Aboriginal people. From an epidemiological standpoint, it would be extremely valuable to examine a range of other $B$. pilosicoli isolates from different sources to determine how widespread these variants are in different host species and geographical regions.

Analysis of the contig on which bla $a_{\text {OXA-136 }}$ resides in the genome of B. pilosicoli $95 / 1000$ failed to identify any structures reminiscent of transposons or integrons. A similar finding was made for $b l a_{\mathrm{OXA}-63}$ in the French strain BM4442 (Meziane-Cherif et al., 2008). Furthermore, the GC content of $b l a_{\text {OXA-136 }}$ in strain $95 / 1000$ was similar to that of the whole contig and the whole genome. Hence if the gene has been acquired by horizontal gene transfer, this is likely either to have been an ancient event or to have been a more recent acquisition from another Brachyspira species or B. pilosicoli strain with a similar GC content, using a different transfer mechanism. The related spirochaete Brachyspira hyodysenteriae contains an unusual prophage-like gene transfer agent named VSH-1 that transfers random $7.5 \mathrm{~kb}$ fragments of spirochaetal DNA between cells, where it may undergo recombination (Matson et al., 2005). A similar transfer agent appears to be present in other Brachyspira species, including the $B$. pilosicoli strain WesB (penicillin-resistant) that was used in the current study (Stanton et al., 2003). The occurrence of this form of gene transfer would help to explain the presence of $\beta$-lactamase genes in resistant strains, without the need to infer that such strains had a different ancestral background to the susceptible strains that apparently lack these genes. Consistent with this, results from multilocus enzyme electrophoresis studies of B. pilosicoli have revealed considerable genetic diversity among strains, and do not obviously separate penicillin-sensitive strains from strains with $\beta$-lactamase genes (Lee \& Hampson, 1994; Trott et al., 1998; data not shown). Once a functional gene is acquired, penicillin use would select for these resistant strains. As pointed out by Brooke et al. (2003), villagers from the highlands of PNG who were carrying susceptible strains are unlikely to have been exposed extensively to penicillins and, due to their isolation, they may not have encountered resistant strains of B. pilosicoli or other Brachyspira species from other sources. On the other hand, despite also being relatively isolated, Australian Aboriginal people in rural settlements are likely to have had exposure to $\beta$-lactams in the course of their treatment for the many health problems that occur within this population (Williams et al., 1997), thus selecting for resistant strains that may have been introduced. Resistance may then have spread to different strains that circulate in these communities (Lee \& Hampson, 1992, 1994; Brooke et al., 2001). Interestingly, among $B$. pilosicoli isolates from homosexual males and recent migrants to Australia from developing countries, approximately half were found to be resistant to amoxicillin and half were susceptible (Brooke et al., 2003). This ratio is presumably governed by the opportunity to acquire $\beta$-lactamase genes from other Brachyspira strains or species, and the extent of pressure for selection of resistant strains caused by penicillin use. Although all four porcine strains in the current study were resistant to penicillin, susceptible strains from pigs have been reported previously (Brooke et al., 2003). Penicillins are frequently used to treat porcine infections, and again this use within a population would select for any resistant strains that are present.

Further work is required to investigate the presence, variation and source of the genes encoding OXA-63, OXA-136 and OXA-137 in B. pilosicoli strains from different regions and host species, to examine the potential distribution of these genes in other Brachyspira species, and to determine whether they can be transferred between strains using the Brachyspira prophage-like gene transfer agent.

\section{ACKNOWLEDGEMENTS}

Thanks are due to Professor Tom Riley for supplying substrates for the antimicrobial sensitivity testing and to Dr George Jacoby for assistance with establishing the OXA numbers of the variant enzymes.

\section{REFERENCES}

Ambler, R. P. (1980). The structure of beta-lactamases. Philos Trans $R$ Soc Lond B Biol Sci 289, 321-331.

Brooke, C. J., Clair, A. N., Mikosza, A. S. J., Riley, T. V. \& Hampson, D. J. (2001). Carriage of intestinal spirochaetes by humans: epidemiological data from Western Australia. Epidemiol Infect 127, 369-374.

Brooke, C. J., Hampson, D. J. \& Riley, T. V. (2003). In vitro antimicrobial susceptibility of Brachyspira pilosicoli isolates from humans. Antimicrob Agents Chemother 47, 2354-2357.

Brooke, C. J., Riley, T. V. \& Hampson, D. J. (2006). Comparison of prevalence and risk factors for faecal carriage of the intestinal spirochaetes Brachyspira aalborgi and Brachyspira pilosicoli in four Australian populations. Epidemiol Infect 134, 627-634.

Bush, K., Jacoby, G. A. \& Madeiros, A. A. (1995). A functional classification scheme for $\beta$-lactamases and its correlation with molecular structure. Antimicrob Agents Chemother 39, 1211-1233.

CLSI (2007). Methods for Antimicrobial Susceptibility Testing of Anaerobic Bacteria. Document M11-A7. Wayne, PA: Clinical and Laboratory Standards Institute.

Dassanayake, R. P., Sarath, G. \& Duhamel, G. E. (2005). Penicillinbinding proteins in the pathogenic intestinal spirochete Brachyspira pilosicoli. Antimicrob Agents Chemother 49, 1561-1563.

Douglas, J. G. \& Crucioli, V. (1981). Spirochaetosis: a remedial cause of diarrhoea and rectal bleeding? Br Med J (Clin Res Ed) 283, 1362.

Esteve, M., Salas, A., Fernandez-Banares, F., Lloreta, J., Marine, M., Gonzalez, C. I., Forne, M., Casalots, J., Santaolalla, R. \& other authors (2006). Intestinal spirochetosis and chronic watery diarrhea: clinical and histological response to treatment and long-term follow up. J Gastroenterol Hepatol 21, 1326-1333.

Fournié-Amazouz, E., Baranton, G., Carlier, J. P., Chambreuil, G., Cohadon, F., Collin, P., Jolivet, A. G., Hermes, I., Lemarie, C. \& Saint 
Girons, I. (1995). Isolations of intestinal spirochaetes from the blood of human patients. J Hosp Infect 30, 160-162.

Hampson, D. J. \& Duhamel, G. E. (2006). Porcine colonic spirochetosis/intestinal spirochetosis. In Diseases of Swine, 9th edn, pp. 755-767. Edited by B. E. Straw, J. J. Zimmerman, S. D’Allaire \& D. J. Taylor. Oxford: Blackwell Publishing.

Hampson, D. J., Oxberry, S. L. \& La, T. (2006a). Potential for zoonotic transmission of Brachyspira pilosicoli. Emerg Infect Dis 12, 869-870.

Hampson, D. J., Stephens, C. P. \& Oxberry, S. L. (2006b). Antimicrobial susceptibility testing of Brachyspira intermedia and Brachyspira pilosicoli isolates from Australian chickens. Avian Pathol 35, 12-16.

Harland, W. A. \& Lee, F. D. (1967). Intestinal spirochaetosis. BMJ 3, 718-719.

Kanavaki, S., Mantadakis, E., Thomakos, N., Pefanis, A., MatsiotaBernard, P., Karabela, S. \& Samonis, G. (2002). Brachyspira (Serpulina) pilosicoli spirochetemia in an immunocompromised patient. Infection 30, 175-177.

Law, C. L. H., Grierson, J. M. \& Stevens, S. M. B. (1994). Rectal spirochaetosis in homosexual men: the association with sexual practices, HIV infection and enteric flora. Genitourin Med 70, 26-29.

Lee, J. I. \& Hampson, D. J. (1992). Intestinal spirochaetes colonizing Aborigines from communities in the remote north of Western Australia. Epidemiol Infect 109, 133-141.

Lee, J. I. \& Hampson, D. J. (1994). Genetic characterisation of intestinal spirochaetes and their association with disease. $J$ Med Microbiol 40, 365-371.

Lima, M. A., Barbosa, A. L., Santos, V. M. \& Misiara, F. P. (2005). Intestinal spirochetosis and colon diverticulosis. Rev Soc Bras Med Trop 38, 56-57.

Margawani, K. R., Robertson, I. D., Brooke, C. J. \& Hampson, D. J. (2004). Prevalence, risk factors and molecular epidemiology of Brachyspira pilosicoli in humans on the island of Bali, Indonesia. $J$ Med Microbiol 53, 325-332.

Matson, E. G., Thompson, M. G., Humphrey, S. B., Zuerner, R. L. \& Stanton, T. B. (2005). Identification of genes of VSH-1, a prophagelike gene transfer agent of Brachyspira hyodysenteriae. J Bacteriol 187, 5885-5892.

Meziane-Cherif, D., Lambert, T., Dupechez, M., Courvalin, P. \& Galimand, M. (2008). Genetic and biochemical characterization of OXA-63, a new class D $\beta$-lactamase from Brachyspira pilosicoli BM4442. Antimicrob Agents Chemother 52, 1264-1268.

Mikosza, A. S. J. \& Hampson, D. J. (2001). Human intestinal spirochetosis: Brachyspira aalborgi and/or Brachyspira pilosicoli? Anim Health Res Rev 2, 101-110.

Munshi, M. A., Traub, R. J., Robertson, I. D., Mikosza, A. S. J. \& Hampson, D. J. (2004). Colonization and risk factors for Brachyspira aalborgi and Brachyspira pilosicoli in humans and dogs on tea-estates in Assam, India. Epidemiol Infect 132, 137-144.

Oxberry, S. L., Trott, D. J. \& Hampson, D. J. (1998). Serpulina pilosicoli, water birds and water: potential sources of infection for humans and other animals. Epidemiol Infect 121, 219-225.

Rozen, S. \& Skaletsky, H. J. (2000). Primer3 on the WWW for general users and for biologist programmers. In Bioinformatics Methods and Protocols: Methods in Molecular Biology, pp. 365-386. Edited by S. Krawetz \& S. Misoner. Totowa, NJ: Humana Press.

Sambrook, J., Fritsch, E. F. \& Maniatis, T. (1989). Molecular Cloning: a Laboratory Manual. Cold Spring Harbor, USA: Cold Spring Harbor Laboratory.

Stanton, T. B., Thompson, M. G., Humphrey, S. B. \& Zuerner, R. L. (2003). Detection of bacteriophage VSH-1 svp38 gene in Brachyspira spirochetes. FEMS Microbiol Lett 224, 225-229.

Sun, T., Nukaga, M., Mayama, K., Braswell, E. H. \& Know, J. R. (2003). Comparison of $\beta$-lactamases of classes $A$ and $D: 1.5-\AA$ crystallographic structure of the class D OXA-1 oxacillinase. Protein Sci 12, 82-91.

Tompkins, D. S., Millar, M., Heritage, J. \& West, A. P. (1987). $\beta$ Lactamase production by intestinal spirochaetes. J Gen Microbiol 133, 761-765.

Trivett-Moore, N. L., Gilbert, G. L., Law, C. L. H., Trott, D. J. \& Hampson, D. J. (1998). Isolation of Serpulina pilosicoli from rectal biopsy specimens showing evidence of intestinal spirochetosis. J Clin Microbiol 36, 261-265.

Trott, D. J., Combs, B. G., Oxberry, S. L., Mikosza, A. S. J., Robertson, I. D., Passey, M., Taime, J., Sehuko, R. \& Hampson, D. J. (1997a). The prevalence of Serpulina pilosicoli in humans and domestic animals in the Eastern Highlands of Papua New Guinea. Epidemiol Infect 119, 369-379.

Trott, D. J., Jensen, N. S., Saint Girons, I., Oxberry, S. L., Stanton, T. B., Lindquist, D. \& Hampson, D. J. (1997b). Identification and characterization of Serpulina pilosicoli isolates from the blood of critically-ill patients. J Clin Microbiol 35, 482-485.

Trott, D. J., Mikosza, A. S. J., Combs, B. G., Oxberry, S. L. \& Hampson, D. J. (1998). Population genetic analysis of Serpulina pilosicoli and its molecular epidemiology in villages in the Eastern Highlands of Papua New Guinea. Int J Syst Bacteriol 48, 659-668.

Voha, C., Docquier, J.-D., Rossolini, G. M. \& Fosse, T. (2006). Genetic and biochemical characterization of FUS-1 (OXA-85), a narrowspectrum class D $\beta$-lactamase from Fusobacterium nucleatum subsp. polymorphum. Antimicrob Agents Chemother 50, 2673-2679.

Williams, P., Gracey, M. \& Smith, P. (1997). Hospitalization of Aboriginal and non-Aboriginal patients for respiratory tract diseases in Western Australia, 1988-1993. Int J Epidemiol 26, 797-805. 